\title{
Self-Concept, Locus Of Control, Media Exposure, And Behavior Of Youth Toward Luxury Products Purchase
}

Panid Kulsiri, Srinakharinwirot University, Thailand

\begin{abstract}
This study was a survey research. It aimed to explore the relationships between three dimensions of self-concept, locus of control, media exposure, and behavior of youth toward the purchase of luxury products. The samples were 363 young people whose ages were between 15 and 25 years old. Questionnaires were employed as the instruments for data collection. Results of the survey showed that respondents, on average, purchased luxury products in general at the low level. Results of the hypotheses test at the statistical significance level of 0.05 suggested that the behavior toward the purchase of luxury products in general has relationships with self-concept in terms of perceived economic status, perceived personal-image and self-roles; and media exposure.
\end{abstract}

Keywords: Luxury Product; Self-Concept; Locus of Control; Media Exposure; Youth, Purchase Behavior

\section{INTRODUCTION}

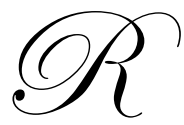

enand (1993) stated that, in particular, the parameters and definition of what constitutes luxury goods is not clearly articulated. There is a strong argument that products cannot be sorted into simple categories of luxury and non-luxury by appearance or intrinsic qualities of the goods themselves. A luxury product is something that is definitely out of the ordinary in terms of daily living needs. To date, the most widely accepted typologies have in common the idea that luxury goods are modifications of a base product that involves satisfying consumer needs (Vickers \& Renand, 2003).

Veblen (1899) argued that luxury products have to be put into their socio-economic context. The consumption of luxury goods is a conspicuous waste. The status of luxury goods depends on both the product attributes and the consumer socio-economic status. An article may be useful and wasteful both, and its utility to the consumer may be made up of use, and waste in the most varying proportions. Furthermore, there is also an argument that the socio-economic context needs to be defined within the context of a country's framework (Vickers \& Renand, 2003).

Besides the question on the definition of the luxury products, the existing marketing literature also shows that little is known about the antecedents of luxury products purchase. In accordance with previous researchers, luxury products have to be put into their socio-economic context. It means that the behavior toward the luxury products of consumers in different environment will not be the same. Therefore, this research aims to focus empirically on the buying behavior of youths in Bangkok toward luxury products and its determinants. The classification of the luxury goods in the context of Thai youths was conducted before proceeding to explore the determinants of the purchase behavior. This study will be useful for marketers in order to understand the Thai markets. It also will enrich our understanding of the antecedents of personal orientation toward luxury products consumption. 


\section{LITERATURE REVIEW}

\section{Buying behavior}

Kotler \& Keller (2009) explained that a consumer's buying behavior is influenced by cultural, social, and personal factors. Culture is the fundamental determinant of a person's wants and behavior. A child growing up in another country might have a different view of self, relationship to others, and rituals. Therefore, this study aimed to explore particularly the behavior of youths in Bangkok.

Regarding the social factors, Kotler \& Keller (2009) explained that they include reference groups, family, and social roles and statuses. These factors affect consumer buying behavior. A person participates in many groups which often are an important source of information and help to define norms for behavior. A role consists of the activities a person is expected to perform. People choose products that reflect and communicate their role and actual or desired status in society. A buyer's decisions are also influenced by personal characteristics which include occupation, economic circumstances, personality and self-concept, and etc. Meanwhile, Lancaster (1966) argued that consumers demand products not in themselves, but for the characteristics that they bundle up. A product exhibiting symbolic interactionism can be defined as having a component that is designed to associate the individual consumer with a desired group, role, or self-image in terms of emotions and personalities (Bhat \& Reddy, 1998). Kotler \& Keller (2009) explained that the economic circumstances include spendable income, savings and assets, debts, borrowing power, and attitudes toward spending and saving. Luxury-goods makers can be vulnerable to an economic downturn.

\section{Self-concept}

Self-concept is defined as the totality of the individual's thoughts and feelings having reference to him- or herself as an object. The aspects of the self that are most valued and most influence consumption and other behaviors vary across cultures. An interdependent construal of the self is based more on the common Asian cultural belief in the fundamental connectedness of human beings. The interdependent self-concept emphasizes family, cultural, professional, and social relationships. Individuals with an interdependent self-concept define themselves in terms of social roles, family relationships, and commonalities with other members of their groups. The self-concept has many dimensions (Hawkins \& Mothersbaugh, 2010).

Kotler \& Keller (2009) explained that each person has personality characteristics that influence his or her buying behavior. Consumers have multiple selves. A single consumer is likely to act quite differently with different people and in different situations or social roles (Markus \& Nurius, 1986).

Sirgy (1982) stated that consumers often choose and use brands that have a brand personality consistent with their own actual self-concept although the match may instead be based on the consumer's ideal self-concept or even on others' self-concept. The actual self-concept is how we view ourselves. The ideal self-concept is how we would like to view ourselves. The others' self-concept is how we think others see us. Graeff (1996) stated that these effects may also be more pronounced for publicly consumed products than for privately consumed goods. Consumers prefer brands that match their self-concepts (Hawkins \& Mothersbaugh, 2010).

Schiffman \& Kanuk (2007) stated that consumers have a variety of enduring images of themselves. These self-images, or perceptions of self, are very closely associated with personality in that individuals tend to buy products and services and patronize retailers whose images or personalities relate in some meaningful way to their brand choice. They tend to approach products with images that could enhance their self-concept and avoid those products that do not (Karande, Zinkhan, \& Lum, 1997). Schiffman \& Kanuk (2007) further explained that when consumers are primarily concerned with the acceptance or approval of others they like, with whom they identify, or those who offer them status or other benefits, they are likely to adopt their product, brand, or other behavioral characteristics. 


\section{Locus of control}

Locus of control refers to a person's belief about what causes the good or bad results in his or her life. Arnould, Price, \& Zinkhan (2004) explained that individuals having an external locus of control tend to ascribe the influence on their lives to luck, fate, chance, other people, or strong forces they cannot overcome - the externals. People having an internal locus of control tend to attribute the influences on their lives to forces such as their own skills that are within their control - the internals. Externals attribute causality to environmental forces while internals assign such attribution to personal forces. Locus of control influences a consumer's ability to form accurate purchase intentions. A stronger internal locus of control leads to smaller discrepancies between intentions and behavior (Cote \& Tansuhaj, 1989). Bearden, Ingram and LaForge (1995) identified two classes of consumer luxury goods as private luxury goods and public luxury goods. If the luxury goods are consumed visibly then interpersonal influences on buying behavior will be significantly greater.

\section{Communication}

Kotler \& Keller (2009) explained that marketing communications are the means by which firms attempt to inform, persuade, and remind consumers, directly or indirectly, about the products and brands they sell. Media are where marketers put their commercial messages and include television, radio, magazines, direct mail, billboards, and the Internet (Hawkins \& Mothersbaugh, 2010).

Hawkins \& Mothersbaugh (2010) explained that information processing is a series of activities by which stimuli are perceived, transformed into information, and stored. The information-processing model has four major steps: exposure, attention, interpretation, and memory. The first three of these constitute perception. Exposure occurs when a stimulus comes within range of a person's sensory receptor nerves. Attention occurs when the stimulus is seen. Interpretation is the assignment of meaning to the received sensations. Memory is the short-term use of the meaning for immediate decision making or the longer-term retention of the meaning. These processes occur virtually simultaneously and are clearly interactive. Both perception and memory are extremely selective. Of the massive amount of information available, individuals can be exposed and attend to only a limited amount. In terms of exposure, an individual can be exposed to only a minuscule fraction of the available stimuli. There are now hundreds of television channels, thousands of radio stations, and innumerable magazines and Web sites.

Hawkins \& Mothersbaugh (2010) further explained that most of the stimuli to which individuals are exposed are self-selected. People deliberately seek out exposure to certain stimuli and avoid others. Ad avoidance appears to increase as advertising clutter increases and as consumer attitudes toward advertising become more negative. The intensity can increase attention. Repetition is related to intensity. It is the number of times an individual is exposed to a given stimuli. Repetition often increases recall. Frequent repetition outperforms limited repetitions. The number o times a message is repeated affects the extent and duration of learning and memory. Repetition enhances learning and memory by increasing the accessibility of information in memory or by strengthening the associative linkages between concepts (Malaviya, Meyers-Levy, \& Sternthal, 1999).

Peter \& Olson (2002) stated that exposure to information is critically important for consumers' interpretation processes. Consumers are exposed to information in the environment, including marketing strategies, primarily through their own behaviors. There are two types of exposure to marketing information: intentional exposure and accidental exposure. Typically, consumers search for relevant marketing information to help solve a purchasing problem.

\section{METHODS}

\section{Data and Sample}

The data were collected by a self-administered questionnaire survey of 363 youth consumers in Bangkok. The response rate was $21.25 \%$. 
Forty percent of the respondents are male. Forty-one percent of the respondents are in the age group of 1519 years old, the rest are equally in the age group of 20-22 and 23-25 years old. Thirty-seven percent of respondents are in the income group of USD161-323, 35\% are in the income group of lower than USD161, and 28\% are in the group of higher than USD323.

The cross-tabulation analysis showed that almost half of the respondents in the lowest income group evaluate their economic status as "having enough money on the basis of being thrifty", whereas other two groups in the higher income level evaluate themselves similarly as "having enough money for spending and saving". The result of the chi-square test confirmed that the evaluation depended on the income significantly at the statistical level of 0.05 .

The respondents were asked to evaluate eight types of products whether they can be categorized as luxury products. Results showed that, on average, almost $70 \%$ of the respondents agreed that these eight products can be classified as luxury products. These products are perfumes, fashioned contact lens, watches, imported clothes, lipsticks, nail polish, imported bags, and imported food.

\section{Variables}

\section{Dependent variable}

In this paper, purchase behavior refers to frequency of purchase of eight types of products that the respondents evaluated as luxury products. The frequency was measured on a 5-point scale that ranged from not at all, rarely, sometimes, often, and regularly.

\section{Independent variables}

The independent variables include self-concept, locus of control, and media exposure. The self-concept refers to the beliefs a person holds about his or her own attributes in terms of economic status, personal image, and social roles. The respondents were asked to assess their economic status as very poor to very rich on a 5-point scale item. The personal image and social roles were measured on five-point multiple-item scales. The scales ranged from the least to the highest scores (1-5).

The locus of control refers to a person's belief about what causes the good or bad results in his or her life. This variable has two dimensions, the external locus of control and the internal locus of control. These two dimensions of the locus of control were measured on five-point multiple-item scales. The scales ranged from the least to the highest scores (1-5).

The media exposure refers to the quantity that a person received information about the luxury products from the media. The media were classified as the mass media, personal contact, and the Internet. The quantity of the exposure from these three channels was measured on five-point multiple-item scales. The scales ranged from the least to the highest scores (1-5).

\section{Hypothesis}

Luxury products purchase is related to self-concept, locus of control, and media exposure.

\section{Analyses}

The hypotheses proposed in this study were tested by a multiple regression analysis, except the one-way ANOVA test was conducted to analyze whether the respondents in the higher group of economic status would buy more than the lower. The statistical significance was tested at the level of 0.05 . The reliability of the scales was assessed by Cronbach's alpha. Results of the Cronbach's alpha test showed the values of .752-.841 which supported the internal consistency of the instruments. 


\section{RESULTS}

Table 1 presents the descriptive statistics of each variable. It is found that the respondents purchased luxury products at low level. The study suggested that the respondents viewed themselves as having the characteristics of self-image, self-roles, externalist, and internalist at moderate level.

They were exposed to information from the mass media and the personal contact at low level of quantity, meanwhile, the Internet exposure was at the highest level.

Regarding the self-image, the respondents were asked to assess themselves as being a good looking person, intelligent, attractive, self-monitored, and happy.

In terms of self-role, the respondents were asked to assess their roles as those who have high experience in life; have knowledge in their works, new technology, and new products; and have used premium products or products with high quality.

Table 1

Descriptive Statistics

\begin{tabular}{lcc}
\hline \multicolumn{1}{c}{ Variables } & $\overline{\mathrm{X}}$ & s.d. \\
\hline Luxury products purchase frequency & 2.05 & .687 \\
\hline Self-image & 3.17 & .523 \\
\hline Self-roles & 3.06 & .567 \\
\hline External locus of control & 3.06 & .651 \\
\hline Internal locus of control & 3.92 & .557 \\
\hline Mass media exposure & 2.59 & .657 \\
\hline Personal contact & 2.75 & .764 \\
\hline The Internet expossure & 4.45 & .827 \\
\hline \hline
\end{tabular}

Table 2 shows the results of the ANOVA used to test the hypothesis on the purchase behavior of each economic status group. It shows significant differences in the frequency of purchase in the groups. From further study, it was found that the group that has moderate economic status significantly bought luxury products less frequent than the rich group.

Table 2

ANOVA of Purchase Behavior by Economic Status

\begin{tabular}{lccccc}
\hline \hline Economic status & $\mathbf{N}$ & $\bar{X}$ & s.d. & Levene's test (sig.) & Brown-Forsythe (sig.) \\
\hline Very Poor & 19 & 2.31 & .777 & .023 & .002 \\
\hline Poor & 72 & 2.00 & .811 & \\
\hline Moderate & $118^{*}$ & 1.84 & .567 & \\
\hline Rich & $144^{*}$ & 2.19 & .640 & \\
\hline Very rich & 10 & 2.37 & .808 & \\
\hline \hline
\end{tabular}

Table 3 presents the multiple regression analysis looking at which variables are associated with frequency of purchase. Results of the analysis show that self-concept has positive relationship with frequency of purchase. In the meantime, it is inconclusive about the direction of the relationship between the media exposure and the frequency of purchase. The mass media exposure and the personal contact have positive relationship, whereas, the Internet has negative relationship with the frequency of purchase. The value of the adjusted R square suggested that these variables can explain significantly $22.4 \%$ of the purchase behavior. 
The scores of the standardized coefficients suggested that self image, mass media exposure, personal contact, self-roles, and the Internet exposure are significantly related to the frequency of purchase, respectively.

Table 3

Multiple Regression Analysis for Purchase Behavior

\begin{tabular}{|c|c|c|c|c|}
\hline & \multicolumn{2}{|c|}{ Unstandardized Coefficients } & \multirow{2}{*}{$\frac{\text { Standardized Coefficients }}{\beta}$} & \multirow[t]{2}{*}{ Sig. } \\
\hline & $\mathbf{B}$ & Std. Error & & \\
\hline (Constant) & .242 & .328 & & .460 \\
\hline Self-image & .361 & .077 & .272 & .000 \\
\hline Self-roles & .147 & .073 & .121 & .045 \\
\hline Internal locus of control & -.028 & .051 & -.026 & .584 \\
\hline External locus of control & -.053 & .063 & -.043 & .400 \\
\hline Mass media exposure & .203 & .054 & .193 & .000 \\
\hline Personal contact & .132 & .047 & .147 & .005 \\
\hline The Internet & -.086 & .043 & -.103 & .044 \\
\hline Adjusted R square $=.224$ & & & Sig. $=.000$ & \\
\hline
\end{tabular}

\section{DISCUSSION}

Results of the research supported the hypotheses on the relationship between self-concept, media exposure and the purchase behavior of youth consumers toward the luxury products. The hypothesis on the relationship between the locus of control and purchase behavior is not supported.

From the analysis we found that the respondents have different purchase behavior in accordance with the difference in their economic status. The positive relationship between the self-concept and the frequency of purchase indicates that the self-concept is a significant indicator of the purchase behavior toward luxury products. Moreover, when people view that they have more important role, they will buy more luxury products. These results are consistent with the explanation of karande, Zinkhan, \& Lum (1997) that consumers tend to approach products with images that could enhance their self-concept. Our results suggest that positive thinking about one-self will encourage people to buy more luxury products. From the study, Thai youths assess themselves as having moderate characteristics of self-image and self-roles. The frequency of their purchase on luxury product was at low level. It means that the marketers should encourage the Thai youth consumers to think positive about them in order to encourage them to buy more luxury products.

The results on media exposure indicate that mass media and personal contact have positive effect on consumers purchase behavior. The result reflects the explanation of Hawkins \& Mothersbaugh (2010) that information processing is a series of activities by which stimuli are perceived, transformed and stored. Most of the stimuli to which individuals are exposed are self-selected. In addition, as Vickers \& Renand (2003) stated that luxury goods are modifications of a base product that involves satisfying consumer needs. Therefore, to encourage consumers to buy a luxury product, they need a creditable communication channel such as mass media or the personal contact.

The major contribution of this research is the enhancement of a better understanding about the buying behavior of Thai youth consumers toward luxury products. Two antecedents of the buying behavior are identified. The result of the study confirmed the perspective on consumer behavior that the external stimuli such as the media as well as the internal process such as the way people view themselves can influence consumers buying behavior.

\section{CONCLUSIONS}

This research was based upon the hypotheses that the self-concept, the locus of control, and the media exposure are determinants of the luxury product purchase. We found that self-concept and media exposure are significant determinants of Thai youth consumers' purchasing behavior. The locus of control has no relationship with the purchase behavior. 
In terms of self-concept, the relationship with the purchase behavior is positive. This result enhances a better understanding about the influence of the way people think about themselves on their behaviors. When consumers have a positive view about themselves, they will purchase luxury products.

In terms of media exposure, the direction of the relationship is inconclusive. It is found that the Internet exposure is negatively related to the purchase behavior, whereas, other two types of media are positively related.

Still, there are many aspects of buying behavior toward luxury products and its antecedents that we have not studied. For the further study, we suggest that the researchers could explore other aspects of buying behaviors by collecting the data such as the methods of payment, the preferred type of luxury products, or the preferred country of origin of the luxury products and so on. Furthermore, researchers should focus more on independent variables in terms of personal characteristics or the product attributes. These additional variables will enable marketers to develop marketing activities for the luxury product markets.

\section{ACKNOWLEDGEMENT}

This study was funded by Srinakharinwirot University.

\section{AUTHOR INFORMATION}

Panid Kulsiri (DBA, Chulalongkorn University) teaches at the Srinakharinwirot University, Thailand. Her research primarily focuses on consumer behavior. E-mail: panidkul@yahoo.com

\section{REFERENCES}

1. Arnold, E., Price, L., \& Zinkhan, G. (2004). Consumers. New York: McGraw-Hill/Irwin.

2. Bearden, W. O., Ingram, N. I., \& LaForge, R. W. (1995). Marketing, Principles and Perspectives. New York: McGraw-Hill/Irwin Inc.

3. Bhat, S. \& Reddy, S. K. (1998). Symbolic and functional positioning of brands. Journal of Consumer Marketing, 15, 1, 32-43.

4. Cote, J. A. \& Tansuhaj, P. S. (1989). "Cultural Bound Assumptions in Behavior Intention Models” in Srull, Thomas (ed.), Advances in Consumer Research, Vol. 2. Provo, UT: Association of Consumer Research.

5. Graeff, T. R. (1996). Image congruence effects on product evaluations. Psychology \& Marketing, August, 481-499.

6. Hawkins, I. D. \& Mothersbaugh, D. L. (2010). Consumer Behavior: Building Marketing Strategy. NY: McGraw-Hill Irwin.

7. Karande, K., Sinkhan, G. M., \& Lum, A. B. (1997). Brand personality and self-concept: Areplcation and extension. AMA Summer Conference, 165-171.

8. $\quad$ Kotler, P. \& Keller, K.L. (2009). Marketing Management. New Jersey: Prentice Hall.

9. Lancaster, K. (1966). A new approach to consumer theory. Journal of Political Economy, 74,132-157.

10. Malaviya, P.; Meyers_levy, J.; \& Sternthal, B. (1999). Ad repetition in a cluttered environment. Psychology \& Marketing, March, 99-118.

11. Markus, H. \& Nurius, P. (1986). Possible selves. American Psychologist, 41, 9, 954-969.

12. Peter, J. P. \& Olson, J. C. (2002). Consumer Behavior and Marketing Strategy. 6th ed. New York: McGraw-Hill Irwin.

13. Renand, F. (1993). In Revue Francaise du Marketing, cahiers pp. 132-133.

14. Schiffman, L. G. \& Kanuk, L. L. (2007). Consumer behavior. New Jersey: Prentice Hall.

15. Sirgy, M. J. (1982). Self-concept in consumer behavior: A critical review. Journal of Consumer Research, December, 9, 287-300.

16. Veblen, T. B. (1899). The Theory of the Leisure Class. Macmillan, New York.

17. Vickers, J. S. \& Renand, F. (2003). The marketing of luxury goods: An exploratory study - three conceptual dimensions. The Marketing Review, 3, 459-478. 


\section{NOTES}

